\title{
Domiciliation of Triatoma pseudomaculata (Corrêa e Espínola 1964) in the Jequitinhonha Valley, State of Minas Gerais
}

\section{Domiciliação de Triatoma pseudomaculata (Corrêa e Espínola 1964) no Vale do Jequitinhonha, Estado de Minas Gerais}

\author{
Girley Francisco Machado de Assis ${ }^{1}$, Bernardino Vaz de Mello Azeredo², \\ Ana Laura Carbajal de la Fuente ${ }^{3}$, Liléia Diotaiuti ${ }^{4}$ and Marta de Lana ${ }^{1,5}$
}

\begin{abstract}
Impact of the vector control program was evaluated eight years after implantation of epidemiological surveillance for Chagas' disease in Berilo, a municipality in the Jequitinhonha Valley of the Brazilian State of Minas Gerais. In all 5,242 domiciliary units (96\% of the total) were inspected and 10 found to be infested by the triatomine bug Triatoma pseudomaculata. Triatomines were found associated with bats inside one house and in the peridomiciles of the other nine. None of the 111 Triatoma pseudomaculata captured was infected with Trypanosoma cruzi. Noireau et al ${ }^{16}$ traps were installed in $(n=8)$ and around $(n=100)$ the infested house but no Trypanpsoma cruzi-infected triatomines were found. None bat, opossums (Didelphis albiventris) and rat captured in the peridomicile were infected with Trypanosoma cruzi although $24 \%$ of the inhabitants of the house infested by Triatoma pseudomaculata were seropositive for the parasite, based on ELISA, IHA and IIF.
\end{abstract}

Key-words: Chagas' disease. Epidemiological surveillance. Triatoma pseudomaculata. Jequitinhonha Valley.

\section{RESUMO}

Oito anos após a implantação da vigilância epidemiológica para doença de Chagas em Berilo, Vale do Jequitinhonha, MG, Brasil, foi realizada uma pesquisa para verificar o impacto do Programa de Controle Vetorial. Neste trabalho, 5.242 (96\%) unidades domiciliares foram vistoriadas. Dez estavam infestadas por Triatoma pseudomaculata. Em nove delas os insetos estavam infestando o peridomicílio e em uma casa foi constatado um foco intradomiciliar associado a morcegos. Foram capturados 111 insetos da espécie Triatoma pseudomaculata e nenhum exemplar estava infectado por Trypanosoma cruzi. Na casa infestada e em torno dela foram instaladas respectivamente 8 e 100 armadilhas de Noireau et al ${ }^{16}$ e nenhum triatomíneo foi capturado. Oitenta morcegos capturados e examinados também estavam negativos para Trypanosoma cruzi bem como três gambás (Didelphis albiventris) e um roedor, todos capturados no peridomicílio. Um porcentual de 24\% dos moradores das casas infestadas por Triatoma pseudomaculata foi sororeativo (ELISA, HAI e IFI) para Tripanosoma cruzi.

Palavras-chaves: Doença de Chagas. Vigilância epidemiológica. Triatoma pseudomaculata. Vale do Jequitinhonha.

The municipality of Berilo is located in the Jequitinhonha Valley, in the northwest of the Brazilian State of Minas Gerais. The region reported intense transmission of Chagas' disease before systematic vector control was initiated ${ }^{8}$. A national survey undertaken in 1975-1980 revealed an infection prevalence of 35.5\% in Berilo, reaching $68.9 \%$ in people aged over $39^{3}$. Afterwards Aguilar ${ }^{1}$ and Montoya ${ }^{15}$ studied some aspects from epidemiology and morbidity of Chagas disease in this municipality.
Control activities against the triatomine vectors of Trypanosoma cruzi in the Jequitinhonha Valley begin in 1960, under the Chagas' Disease Control Program (CDCP). In 1982, the first survey of triatomine distribution in this region found $6 \%$ of houses to be infested, predominantly with Panstrongylus megistus. During this survey Triatoma pseudomaculata characterized by Corrêa e Espinola ${ }^{5}$ was detected for the first time in Berilo. Continuous spraying with insecticides was performed in the municipality

\footnotetext{
1. Núcleo de Pesquisas em Ciências Biológicas, Universidade Federal de Ouro Preto, MG. 2. Secretaria do Estado da Saúde, Belo Horizonte, MG. 3. Departamento de Entomologia, Fundação Instituto Oswaldo Cruz, Rio de Janeiro, RJ. 4. Centro de Pesquisa René Rachou, Belo Horizonte, Fundação Instituto Oswaldo Cruz, Belo Horizonte, MG. 5. Departamento de Análises Clínicas, Escola de Farmácia, Universidade Federal de Ouro Preto, Ouro Preto, MG.

Logistical and financial support: FAPEMIG, CNPq, SESU/MEC and PROEX/UFOP.

Address to: Prof ${ }^{a}$ Marta de Lana. Dept ${ }^{\circ}$ de Análises Clínicas/EF/UFOP. Rua Costa Sena 171, 35400-000 Ouro Preto, MG.

Telefax: $55313559-1680$

e-mail: delana@nupeb.ufop.br

Recebido em: 22/02/2007

Aceito em: 21/062007
} 
from 1985-1989, producing clear reductions (90 and 80\% respectively) in domiciliary and peridomiciliary triatomine infestations. Although the predominant species in 1989-1997 was still Panstrongylus megistus, Triatoma vitticeps, Triatoma sordida, Panstrongylus geniculatus, Panstrongylus diasi and Triatoma pseudomaculata were also recorded. This last species was the least prevalent, corresponding to only $1 \%$ of triatomines sampled. It occurs in semi-arid areas from Northeast from Brazil, states of Minas Gerais (N and NE), Piauí and Goiás, particularly in peridomiciliary which it is able to re-invade from natural ecotopes $^{4}$. Specimens of Triatoma pseudomaculata can be collected in dovecots, chicken houses, fences, roof spaces, tree holes and piles of firewood or bricks.

Control of this species is particularly difficult due its widespread, sylvatic distribution ${ }^{6}$ and Triatoma pseudomaculata is currently considered to be one of the five triatomines most commonly sampled in Brazil 7 .

A vector surveillance programme was set up in Berilo in 1997, in accordance with standard CDCP methodology ${ }^{13}$. The effectiveness of control measures in recent years was evaluated by performing a triatomine sampling survey.

\section{MATERIAL AND METHODS}

Characteristics of the study area. Berilo (10 $50^{\circ} 06^{\prime \prime}$; $42^{\circ} 27^{\prime} 56^{\prime}$ 'W) is located in NE Minas Gerais, within the Jequitinhonha Valley mesoregion, $660 \mathrm{~km}$ from the state capital of Belo Horizonte, It lies at $401 \mathrm{~m}$ of latitude and has an area of $581.5 \mathrm{~km}^{2}$. According to the 2000 IBGE census, the total population is 12,979, of which $3,031(23.4 \%)$ live in the town itself and 9,948 (76.6\%) in the surrounding rural area, distributed among 30 communities. The predominant biome of the mesoregion is cerrado, characterised by a hot, semi-humid and seasonal climate, with a mean annual with a mean temperature of $24^{\circ} \mathrm{C}$ and rainfall of $800-1600 \mathrm{~mm}$, the latter restricted to a few months of the year. Soils are generally very old, chemically poor and deep and together with the lack of governmental support for farmers, provide difficult conditions for agriculture.

Triatomine survey. The triatomine survey was carried out in collaboration with the Minas Gerais State Health Secretariat (SES-MG) and Regional Management Health from Diamantina. All domiciliary units (DUs) in the rural and urban areas of Berilo were surveyed from February 2005 to January 2006.

Capture of triatomines. Triatomines were captured manually with flashlights and forceps in and around all the houses and their respective outbuildings.

All DUs found to contain triatomines or signs of infestation were immediately treated with the insecticide alphacypermethrin ( $40 \%$ wettable powder). Triatomines were transported to the laboratory for examination and identification.

Identification of triatomines. Triatomines were identified based on external morphology, using the keys of Lent and Wygodzinsky ${ }^{12}$ and classified according to place of capture, species, developmental stage and presence or absence of Trypanosoma cruzi infection.
Examination of triatomine faeces or urine. The search of flagellates was carried out by examination of freshly removed guts, obtained by abdominal compression or dissection of triatomines in saline solution. One hundred microscopic fields were examined under a magnification of 400X.

Prevalence of Trypanosoma cruzi infection among occupants of Triatoma pseudomaculata infested DUs. The prevalence of Trypanosoma cruzi infection was evaluated among the occupants of DUs infested by Triatoma pseudomaculata, based on the results of serological tests (ELISA + IHA or IIF). Conventional serological tests were performed as recommended by WHO and the Brazilian Ministry of Health ${ }^{1422}$, both of which recommend the use of at least two serological tests with distinct principles to confirm diagnosis of Chagas' disease.

Blood samples $(3 \mathrm{~mL})$ were collected from all participants who had read and signed an informed consent form approved by the CPqRR Ethical Committee (Process 07/2002). This study complied with resolution number 196/1996 of the National Health Council for research involving humans.

ELISA was carried out according to Voller et al ${ }^{21}$ with some modifications. IHA was carried out using a Bio-Mérieux Hemacruzi kit, following the manufacturer's recommendations. IIF was performed using the methodology of Vitor \& Chiari ${ }^{20}$ with an antigenic preparation of Trypanosoma cruzi strain $\mathrm{Y}$.

Areas of occurrence of captured triatomines. The geographical coordinates of all infested DUs were acquired using a hand-held Global Position System (GPS) apparatus (Garmin's etrex personal navigator) and use to construct a map of the distribution of Triatoma pseudomaculata in the municipality, using the Professional MapInfo Program 6.5.

Examination of the domiciliary focus of Triatoma pseudomaculata. Intradomicile: one intradomiciliary focus of Triatoma pseudomaculata was found with many triatomines observed in the roof. Following standard procedure, this house was sprayed immediately with alphacypermethrin $\left(25 \mathrm{mg}\right.$ a.i. $\left./ \mathrm{m}^{2}\right)$ after sample of a few specimens. Survival of the triatomine infestation was evaluated on a second visit made three months later, by setting up eight Noireau et al ${ }^{16}$ traps overnight in the roof.

Potential reservoir animals were also sampled. Bats in the roof were captured using gloves. Aseptic blood samples of domestic animals were collected with heparin for culture (hemoculture) and fresh examination. Sera or plasma were examined by serological testing with Trypanosoma cruzi antigens.

Peridomicile: the peridomicile (chicken houses and barns) was surveyed according to the methodology described above (manual capture) and below.

Sampling of synanthropic animals. Twenty traps $(20 \times 20 \times 60 \mathrm{~cm})$ were distributed within a $100 \mathrm{~m}$ radius of the infested DU on three consecutive nights to sample rodents and opossums. Banana, cheese and steak were used as bait. The traps were installed approximately at 18:30 and inspected the next morning, after being left in place approximately $14 \mathrm{~h}$. 
Search for triatomines in silvatic ecotopes. Triatomines were sought within a $800 \mathrm{~m}$ radius of the infested DU using 100 Noireau et al ${ }^{16}$ traps placed in tree trunks, rock crevices, birds' nests and animal burrows. The traps were left in place for approximately 14h (19:00 to 09:00h). Several tree trunks were also dismantled over a white sheet to look for triatomines.

Examination of reservoir animals. All captured animals were anaesthetised with barbiturate and submitted to xenodiagnosis using $103^{\text {rd }}$ stage nymphs of Triatoma vitticeps. After feeding the insects were kept at $28^{\circ} \mathrm{C}$ and examined 30 days later under the microscope to confirm the presence of flagellates.

The blood of each animal captured in the peridomicile was examined under the microscope to look for Trypanosoma cruzi or other flagellates. Blood with heparin was cultivated in LIT media (hemoculture) and processed according to the methodology of Filardi and Brener ${ }^{10}$. The hemoculture was kept at $28^{\circ} \mathrm{C}$, homogenised every two days and examined under the microscope at 30, 45, 60, 75 and 90 days to look for Trypanosoma cruzi. Sera or plasma were examined by IHA to detect Trypanosoma cruzi infection using the methodology described above.

\section{RESULTS}

Triatomine survey. During the triatomine survey 5,242 of the 5,455 DUs (96\%) in Berilo were visited, remaining 213 unoccupied. Only one householder refused to allow his house to be surveyed. Of the 5,242 DUs visited 1,385 (26.4\%) were urban and 3,857 (73.6\%) rural.

The triatomine species captured were Panstrongylus megistus (280) and Triatoma pseudomaculata (111) being the majority detected in peridomicile (Table 1).

The presence of Triatoma pseudomaculata was confirmed in 10 DUs out of 35 infested DUs (28.6\%) with a total of 111 insects captured, resulting in an DU infestation index (no. infested DU/no. examined DU x 100) of $0.2 \%$ and a dispersion index (no. infested localities/no. examined localities x 100) of $5.4 \%$. No triatomines were found to be infected with Trypanosoma cruzi when examined in the laboratory. In nine DUs, triatomines were captured in peridomicile and in one house insects were captured indoors characterizing colonization. The intradomiciliary insects were associated with bats and to the wood of the roof. All the triatomines present in peridomiciles were detected in chicken houses.

Prevalence of Trypanosoma cruzi infection in inhabitants of DU colonized by Triatoma pseudomaculata. Serology for Trypanosoma cruzi was positive in seven of the 29 individuals examined, most of them (85.7\%) aged over 30 years old (Table 2).

Areas of occurrence of captured triatomines. Triatoma pseudomaculata was the predominant species in the localities close to Virgem da Lapa, Francisco Badaró and Grão Mogol (Figure 1).
Description of domiciliary focus of Triatoma pseudomaculata. TheDU infested by Triatomapseudomaculata (Figure 2) had walls constructed of adobe and mud, with three people sharing four bedrooms, a living room, dining room and kitchen. There was a chicken coop in the peridomicile as well as a barn, wood-burning stove and several other structures that could be occupied by triatomines, including piles of firewood and bricks.

Table 1 - Distribution of triatomine species captured in intra and peridomicile during the triatomine survey.

\begin{tabular}{lccc}
\hline & \multicolumn{3}{c}{ Place of capture } \\
\cline { 2 - 4 } Species & intradomicile & peridomicile & Total \\
\hline Panstrongylus megistus & 62 & 218 & 280 \\
Triatoma pseudomaculata & 9 & 102 & 111 \\
\hline Total & 71 & 320 & 391 \\
\hline
\end{tabular}

Table 2 - Prevalence of positive serology for Trypanosoma cruzi in inhabitants of 10 domiciliary units infested by Triatoma pseudomaculata in the municipality of Berilo.

\begin{tabular}{lccc}
\hline Age (years) & Examined & Positive & Percentage \\
\hline$\leq 15$ & 5 & 1 & 20.0 \\
$16-29$ & 8 & 0 & 0.0 \\
$30-49$ & 7 & 2 & 28.6 \\
$\geq 50$ & 9 & 4 & 44.4 \\
\hline Total & 29 & 7 & 24.1 \\
\hline
\end{tabular}

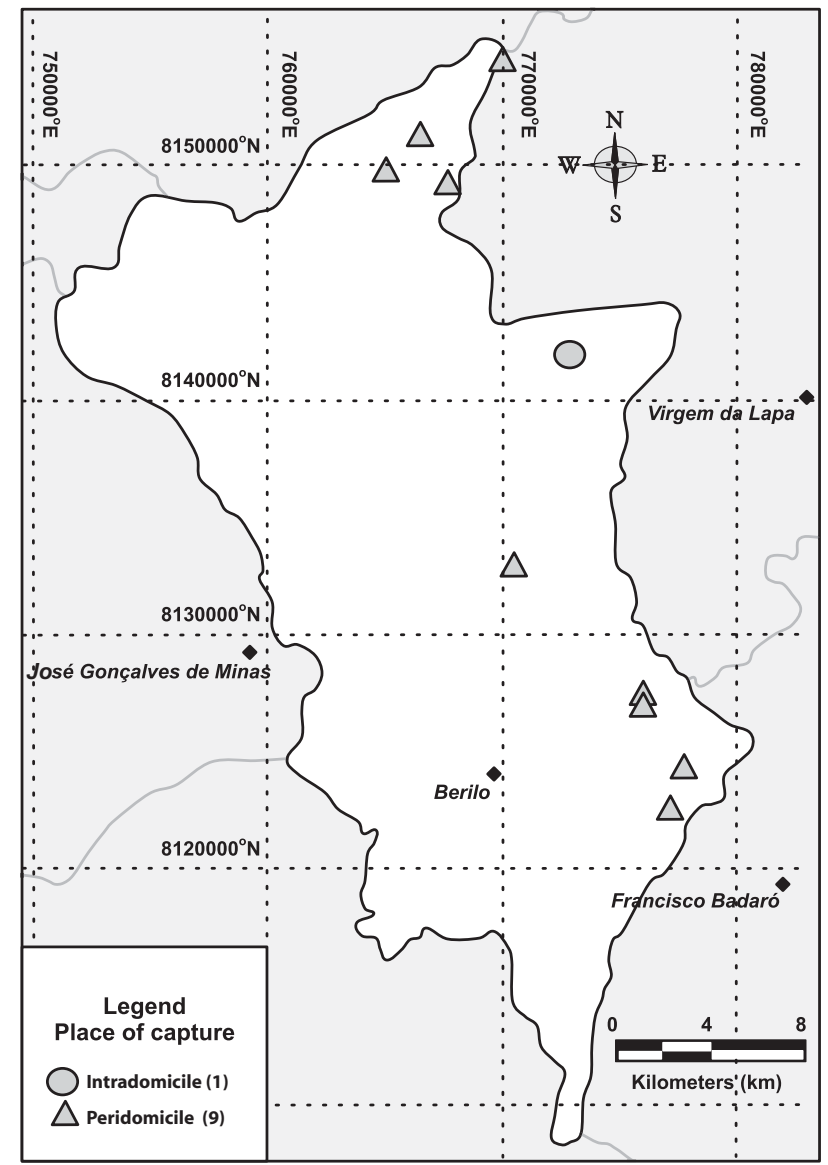

Figure 1 - Distribution of domiciliary units infested by Triatoma pseudomaculata in Berilo. 


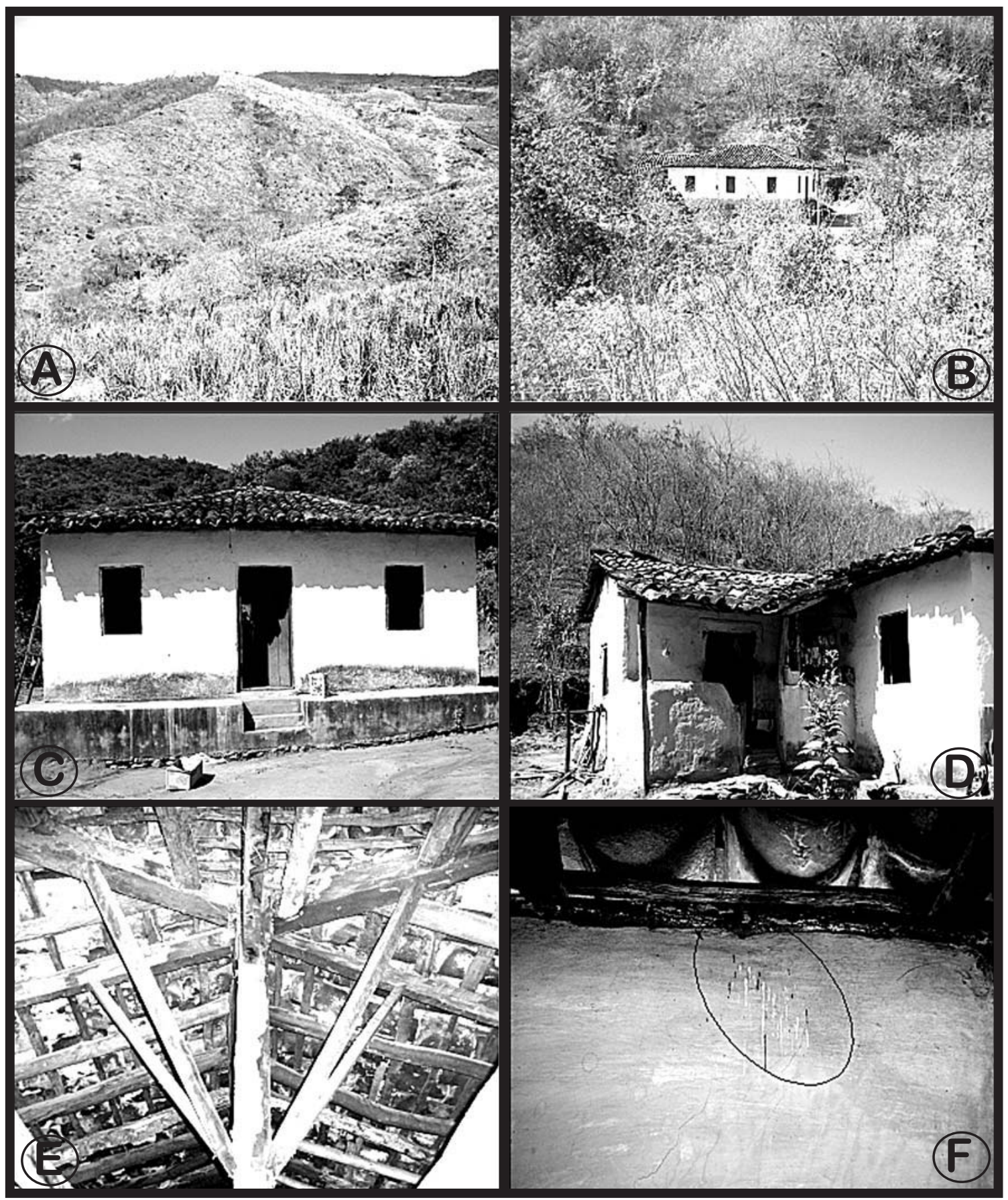

Figure 2 - Environmental characteristics of the area, showing bome colonized by Triatoma pseudomaculata, in the municipality of Berilo. A: Deforested area around infested home. B: View of the infested home. C and D: External views (front and side) of infested home. E: Roof space. F: Remains of feces on wall of living room.

The colony was constituted by around 100 triatomines, but only six triatomines were captured, comprising three adults and three $5^{\text {th }}$ instar nymphs. The insects were associated with old wood in the roof and bats. None of these insects was found to be infected with Trypanosoma cruzi. No triatomines were found in the peridomicile of this house but faeces were noted on the walls of the living room, bedrooms and wood of the bed. Approximately 300 bats (Myotis nigricans) were also observed living in the roof of this house. Eighty were subjected to xenodiagnosis using $3^{\text {rd }}$ instar nymphs of Triatoma vitticeps reared in the laboratory. All were negative for Trypanosoma cruzi infection.
The house was occupied by a woman, aged 64 and two children. Only the woman presented positive serology (ELISA, IHA and IIF) for Trypanosoma cruzi. According to the occupants, triatomines were frequently observed inside the house, but they did not associate these with Chagas' disease.

No triatomines were taken in Noireau traps in the roof, peridomicile, or surrounding undergrowth, or in the trunks of nine trees subjected to careful examined.

All reservoir animals captured in the peridomicile (three opossums Didelphis albiventris and one rat) were negative based 
on examination of fresh blood, hemoculture, xenodiagnosis and serological testing by HAI.

During the visit made four months after insecticidal treatment, an adult female of Triatoma pseudomaculata was captured in one of the bedrooms of the house. This specimen was not infected with Trypanosoma cruzi.

\section{DISCUSSION}

During the triatomine survey in Berilo both Panstrongylus megistus and Triatoma pseudomaculata were captured, mostly in the peridomicile and especially inside chicken houses. The absence of Trypanosoma cruzi infection in triatomine captured may be associated with the presence of chickens, which are refractory to infection with this protozoan.

In recent years, Triatoma pseudomaculata has become adapted to artificial ecotopes, with the peridomiciliary colonisation index increasing in several states, prompting the need for further investigations of its biology ${ }^{6}$. According to Oliveira-Filho et al. ${ }^{17}$ the peridomicile is the principal factor associated with domiciliary infestation in areas occupied by the triatomines and control of these populations is very important. Dias ${ }^{7}$ discussed the difficulties in controlling this species.

The process of intradomiciliation by Triatoma pseudomaculata has been verified only once, in Sobral, a small City in the Brazilian State of Ceará ${ }^{11}{ }^{18}$. The present study represents the second description of an intradomicilary focus of Triatoma pseudomaculata. The absence of infection in 80 bats that were clearly associated with the triatomines, suggests that transmission of Trypanosoma cruzi was not occurring among these animals.

The serological investigation for Trypanosoma cruzi infection among the inhabitants of the houses infested by Triatoma pseudomaculata revealed high prevalence of seropositive cases in people up to 30 years old. Probably most of these cases originated from a period when transmission was higher. Only one adolescent (15 years old) was diagnosed as seropositive and treated by our team $^{2}$. This might have been due to congenital transmission ${ }^{219}$, rather than infection by Triatoma pseudomaculata. Moreover Montoya et $\mathrm{al}^{15}$ and Borges et $\mathrm{al}^{2}$ described a low prevalence of Trypanosoma cruzi infection in young people of this municipality.

The first report of Triatoma pseudomaculata in Berilo was during the triatomine survey of 1982, when this species had no epidemiological importance. Nowadays, Triatoma pseudomaculata adults are frequently captured in houses by the local people and have colonised the peridomicile. These data were verified during our triatomine survey and by the epidemiological surveillance installed in this municipality since 1997 (Machado de Assis et al: unpublished data). It would be interesting to investigate the correlation between the bugs' ability to invade houses and changes in environment characteristics over recent decades, particularly the influence of deforestation and changes in relative humidity. The domiciliary invasion by sylvatic triatomines in Berilo is a constant threat. Epidemiological surveillance needs to be improved in order to carry on the work of the Chagas Disease Control Programm.

\section{ACKNOWLEDGMENTS}

We would like to thank Dr. Bruce Alexander from Liverpool University, England, for English revision and Luis Felipe Soares Cherem from Department of Cartography, UFMG, Brazil, for your help in map. We are grateful to the Berilo municipal authorities.

\section{REFERENCES}

1. Aguilar HM. Epidemiologia da doença de Chagas: Aspectos históricos, sociais, e morbidade em duas áreas endêmicas de Minas Gerais, Brasil. Tese de Mestrado, Instituto Oswaldo Cruz, Rio de Janeiro, RJ, 1988

2. Borges JD, Assis GFM, Gomes LV, Dias JCP, Pinto IDM, Martins-Filho A0, Torres RM, Viñas PA, Bahia MT, Machado-Coelho GL, Lana M. Seroprevalence of Chagas disease in schoolchildren from two municipalities of Jequitinhonha Valley, Minas Gerais, Brazil; six years following the onset of epidemiological surveillance. Revista do Instituto de Medicina Tropical de São Paulo 48: 81-86, 2006.

3. Camargo ME, Da Silva GR, De Castilho EA, Silveira AC. Inquérito sorológico da prevalência da infecção chagásica no Brasil, 1975/1980. Revista do Instituto de Medicina Tropical de São Paulo 26: 192-204, 1984.

4. Carcavallo RU, Girón IG, Juberg J, Lent H. Distribuição geográfica e dispersão altilatidudinal. In: Rodolfo U. Carcavalho, Itamar Galíndez Girón, José Juberg e Herman Lent. Atlas dos vetores da Doença de Chagas nas Américas. Fundação Oswaldo cruz, Rio de Janeiro Vol. III, cap. 17, p. 747-793, 1999.

5. Corrrêa RR, Espínola HN. Descrição de Triatoma pseudomaculata, nova espécie de triatomíneo de Sobral. Ceará. Arquivo de Higiene e Saúde Publica 29: 115-127, 1964.

6. Dias JCP. 0 controle da doença de Chagas no Brasil. Revista da Sociedade Brasileira de Medicina Tropical 24 (supl II): 201-202, 1991.

7. Dias JCP. 0 controle da doença de Chagas no Brasil. In: Silveira AC, Arias AR, Segura E, Guilén G, Russomando G, Schenone H, Dias JCP, Padilla JV, Lorca M, Salvatella R. 0 controle da doença de Chagas nos países do Cone Sul da América: História de uma iniciativa internacional 1991/2001. Faculdade de Medicina do Triângulo Mineiro, Uberaba. p. 145-237, 2002.

8. Dias JCP, Loyola CCP, Brener E. Doença de Chagas em Minas Gerais: Situação atual e perspectivas. Revista Brasileira de Malariologia e Doenças Tropicais 37: 7-28, 1985.

9. Dias JCP, Machado EMM, Fernandes AL, Vinhães MC. Esboço geral e perspectivas da doença de Chagas no Nordeste do Brasil. Cadernos de Saúde Pública 16 (supl 2): 13-34, 2000.

10. Filardi LS, Brener Z. Susceptibility and natural resistance of Trypanosoma cruzi strains to drugs used clinically in Chagas disease. Transactions of the Royal Society of Tropical Medicine and Hygiene 81: 755-759, 1987.

11. Frota FCC, Lima JWO, Braga VSS. Infecção humana pelo Trypanosoma cruzi, num foco urbano de Triatoma pseudomaculata, na cidade de Sobral. Norte do Ceará. Revista da Sociedade Brasileira de Medicina Tropical 32 (supl I): 85-86, 1999.

12. Lent $\mathrm{H}$, Wygodzinsky P. Revision of the Triatominae (Hemiptera, Reduviidae), and their significance as vectors of Chagas disease. Bulletin of American Museum of Natural History 163: 127-520, 1979.

13. Ministério da Saúde. Manual de normas técnicas da campanha de controle da doença de Chagas. Centro de documentação do Ministério da Saúde, Brasília, 1980.

14. Ministério da Saúde. Normas técnicas para coleta, processamento e transfusão de sangue, componentes e derivados. Diário Oficial da União, Portaria $n^{0} .721$, Brasília, 1998. 
15. Montoya R, Dias JCP and Coura JR. Chagas disease in a community in southeast Brazil. I. A serologic follow-up study on a vector controlled area. Revista do Instituto de Medicina Tropical de São Paulo 45:269-274, 2003.

16. Noireau F, Abad-Franch F, Valente SAS, Dias-Lima A, Lopes CM, Cunha V, Valente VC, Palomeque FS, Carvalho-Pinto CJ, Sherlock I, Aguilar M, Steindel M, Grisard EC, Jurberg J. Trapping Triatominae in sylvatic habitats. Memórias do Instituto Oswaldo Cruz 97: 61-63, 2002.

17. Oliveira-Filho AM, Melo MTV, Santos CE, Faria Filho OF, Carneiro FCF, Oliveira-Lima JW, Vieira JBF, Gadelha FV, Ishihata J. Tratamentos focais e totais com inseticida de ação residual para o controle de Triatoma brasiliensis e Triatoma pseudomaculata no Nordeste brasileiro. Cadernos de Saúde Pública 16 (supl 2): 105-111, 2000.

18. Souza LC, Frota FCC, Souza JÁ, Zuza CAS, Lima JWO. Descrição de um foco urbano de Triatoma pseudomaculata na cidade de Sobral. Norte do Ceará.
Resultados Preliminares. Revista da Sociedade Brasileira de Medicina Tropical 32 (Supl I): 84-85, 1999.

19. Valadares HMS, Freitas JM, Martins HR, Lana M, Galvão LMC, Schijman AG, Machado CR, Pena SDJ, Macedo AM. Chagas disease: Study of five cases of congenital transmission using kDNA signature, microsatellites, mitochondrial COII typing and rDNA profiles. In: Abstract of the XXXII Annual Meeting on Basic Research in Chagas' disease. p. 89-BM042. Caxambu, MG, Brazil, 2005.

20. Vitor RW, Chiari E. Evaluation of Trypanosoma cruzi antigens for the indirect hemagglutination reaction. I. Different antigenic extracts. Revista do Instituto de Medicina Tropical de São Paulo 29:178-182, 1987.

21. Voller A, Bidwell D, Bartelett A. Enzyme immunoassays in diagnostic medicine. Bulletin of the World Health Organization 53: 55-65, 1976.

22. World Health Organization. Control of Chagas Disease. Technical Report Series 81: 38-47, 1991 